\title{
ASSESSMENT OF HHV-6 AND HHV-7 IN PATIENTS AFTER KIDNEY TRANSPLANTATION
}

\author{
Inese Folkmane*,**,***, Svetlana Čapenko**, Inara Ādamsone*, \\ Elizabete Folkmane ${ }^{\star * *}$, and Modra Murovska** \\ * Latvian Transplantation Centre, Pauls Stradinš University Hospital, Pilsoṇu iela 13, Rīga, LV-1002, LATVIA; \\ folkmane.inese@inbox.Iv \\ ${ }^{* *}$ Augusts Kirhenšteins Institute of Microbiology and Virology, Rīga Stradinš University, Rātsupītes iela 5, Rīga, LV-1067, LATVIA \\ ${ }^{* * *}$ Faculty of Medicine, University of Latvia, Šarlotes iela 1a, Rīga, LV-1001, LATVIA
}

Contributed by Modra Murovska

\begin{abstract}
Human herpesviruses HHV-6 and HHV-7 reactivation in transplantation is associated with indirect immunomodulatory effects, such as cytomegalovirus (CMV) disease, increased opportunistic infections, graft dysfunction and acute rejection (AR). In this study, we analysed the clinical and immunological outcomes in renal transplant recipients (RTR) with active HHV-6 and HHV-7 infection. Between January 2007 and December 2007, clinical, virological and immunological tests were carried out in 46 RTR. The patients were divided into three groups: with active HHV-6 infection; with active HHV-7 infection; and without infection (control). The mean follow-up was $14 \pm 2.5$ months. At three months after renal transplantation (RT), active CMV infection was present in 12 (26\%); HHV-6 in four (8.6\%); and HHV-7 in nine (19.5\%) of RTR. Active B-herpesviruses infection was not associated with more frequent $A R$ and worsening of graft function in recipients at different times after $R T$. The lymphocyte subsets (CD3+; CD4+ and CD8+ cell count) were considerably lower in RTR before RT. At 3 months after RT CD19+ and CD25+ cell counts were significantly increased in the HHV-7 group compared with the control group $(\mathrm{P}<0.05)$. Significant differences were not found in clinical and immunological outcomes between patients with active B-herpesviruses infection and those without active B-herpesviruses infection.
\end{abstract}

Key words: human herpes virus, immunosuppression, renal transplantation, viral infections, lymphocyte subsets.

\section{INTRODUCTION}

Human herpesviruses (HHV)-6 and -7 belong to the Betaherpesvirinae subfamily and are closely related to another member of the subfamily, cytomegalovirus (CMV). Infection with HHV-6 and HHV-7 commonly occurs in childhood and then subsequently results in life-long latency such that the seroprevalence rate in adults is over 90\% (Yamanishi, 2001).

Primary HHV-6 infection has been associated with febrile illness, including exanthem subitum and infection, which are most likely transmitted by means of saliva. The infection usually occurs during the first two years of life. The virus uses CD46 as a cellular receptor and therefore HHV-6 may also infect other cell types, such as monocytes, epithelial and endothelial cells (Santoro et al., 1999). The clinical course of primary HHV-6 infection is generally benign and self-limited. However, several severe complications have been reported, including encephalitis/encephalopathy, hepatitis and thrombocytopenia (Yoshikawa, 2003). Infection with HHV-7 is also widespread in the population, with primary infection occurring early in life, probably through salivary transmission. HHV-7 has also been associated with febrile illness in children and is another etiologic agent of exanthem subitum (Tanaka et al., 1994). The virus uses CD4 as a cellular receptor to infect T cells (Lusso et al., 1994).

In adult solid organ transplant recipients, while primary infection is uncommon, reactivation of endogenous latent viruses seems to occur very frequently with infection rates of 30-50\% reported in studies (Mendez et al., 2001; Razonable et al., 2005). The stimulus for reactivation of betaherpesviruses is an immunosuppressive (IS) regimen in renal transplant (RT) recipients. However, these viruses possess immunomodulating properties, including the ability to alter the expression of immune activation molecules, modulate expression of several cytokines and chemokines and induce apoptosis in lymphocytes, which may contribute to immunosuppression. Productive infection of CD4 T-cells results in cytopathic effects and cell destruction (Lusso, 
2006). It has been suggested that the HHV-6 infection and activation result in clinical symptoms, including fever, skin rash, interstitial pneumonitis, bone marrow suppression, encephalitis, and rejection (Snydman et al., 2001). In contrast to studies of HHV-6 infection in organ-transplant recipients, the number of studies examining HHV-7 infection in RT patients is limited. According to several recent studies, HHV-7 may act as a co-factor for CMV activation and CMV disease development in organ-transplant recipients (Osman et al., 1996).

A growing body of evidence suggests that the major impact of HHV-6 and HHV-7 reactivation in transplantation is related to indirect immunomodulatory effects, such as their association with CMV disease, increased opportunistic infections, graft dysfunction and rejection (Mendez et al., 2001; Chapenko et al., 2009).

In the present study we estimated the prevalence of latent and active HHV-6 and HHV-7 infection and the association of this infection with clinical and immunological parameters of graft outcome in renal transplant recipients.

\section{MATERIALS AND METHODS}

Fifty recipients receiving transplants at the Latvian Transplant Centre between January 2007 and December 2007 and 27 deceased renal allograft donors were included in this prospective study. The mean follow-up was $14 \pm 2.5$ months. Four early graft losses (until three months) occurred due to arterial graft thrombosis $(n=1)$ and death $(n=$ 3 ). The causes of death were surgical peritonitis, pulmonary embolism, and one unknown cause as the patient was lost during follow up. Thus, further clinical, virological data and immunological tests were carried out in 46 of the 50 patients at 12 months. EDTA blood samples were collected from the patients before transplantation, at two weeks, and 3, 6 and 12 months after transplantation.

Nested polymerase chain reaction (nPCR) was used for the detection of viral genomic sequences in DNA isolated from peripheral blood leukocytes (PBL) and plasma (markers of latent/persistent and active infection, respectively). DNA was isolated from whole blood using the phenol-chloroform method. The QIAamp DNA Blood Mini Kit was used to extract DNA from plasma. $\beta$-globin PCR was applied to check DNA quality. The corresponding primer pairs were used for the detection of CMV, HHV-6 and HHV-7 genomic sequences (Secchiero et al., 1995, Berneman et al., 1992; Studahl et al., 1995) in DNA isolated from whole blood and plasma. To exclude the possibility of contamination during the PCR, HHV-6 and HHV-7 negative DNA, as well as water controls, were included in each experiment. The amplification products were visualised in $1.7 \%$ agarose gel with ethidium bromide staining and analysed using the Kodak Electrophoresis Documentation and Analysis System (EDAS) 290 ASV.

Restriction endonuclease analysis was carried out using enzyme HindIII for the detection of HHV-6 virus variants.
This enzyme cuts HHV-6B $163 \mathrm{kbp}$ amplimer into two fragments: 66 and $97 \mathrm{kbp}$ and does not cut HHV-6A amplimer. In this way, HHV-6A and HHV-6B virus variants were distinguished.

The concentrations of lymphocyte subsets (CD3+, CD4+, $\mathrm{CD} 8+, \mathrm{CD} 4+/ \mathrm{CD} 8+, \mathrm{CD} 19+$ and $\mathrm{CD} 25+$ in $1 \mathrm{~mm}^{3}$ of blood) were measured using a flow cytometer (Becton\& Dickinson). The numbers of total lymphocytes in each cell subset were expressed as absolute counts.

Clinical parameters (immunosuppressive regimens, acute rejection episodes, transplant function and late complications) were obtained through medical records.

Initial immunosuppression in all patients consisted of cyclosporine (CsA), mycophenolate mofetil (MMF) and prednisolone $(\mathrm{P})$ and induction with monoclonal anti-CD25 antibodies (Basilixibam/Daclizumab). Maintenance immunosuppression consisted of CsA, MMF and P. Treatment with oral CsA in microemulsion was started before surgery $(10 \mathrm{mg} / \mathrm{kg} / \mathrm{d})$ to obtain therapeutic CsA blood levels and then was adjusted, based on a target level of 150-250 ng/ml during the first four weeks and 150-200 ng/ml thereafter. The maintenance dose of orally administered MMF was $1.0-2.0 \mathrm{~g} / \mathrm{d}$. Methylprednisolone $5.0 \mathrm{mg} / \mathrm{kg} / \mathrm{d}$ was administered on three consecutive days from the day of RT. Oral prednisolone was started on the first day after operation at $0.5 \mathrm{mg} / \mathrm{kg} / \mathrm{d}$ and reduced gradually till $5.0-10 \mathrm{mg} / \mathrm{d}$.

Acute rejection (AR) episodes were diagnosed on the basis of characteristic clinical features and were confirmed by percutaneous biopsy. The histological features were graded according to the Banff 2005 classification. AR episodes were treated with intravenous methylprednisolone at 500 $\mathrm{mg} / \mathrm{d}$ for three consecutive days. Steroid resistant cases were treated with anti-thymocyte globulin (ATG) at $4 \mathrm{mg} / \mathrm{kg}$ for 7-10 days.

Statistical analysis. Data were expressed as means and standard deviations. Statistical differences between groups were assessed by analysis of variance (ANOVA) or Chisquare and $t$-test. A $P$-value $<0.05$ was considered statistically significant.

The study was performed in accordance with the permission of the Local Ethics Committee and all the participants gave informed consent before the examination.

\section{RESULTS}

Latent/persistent $\beta$-herpesviruses infection was detected in 23 of $27(85 \%)$ transplant donors. CMV infection was found in seven (26\%), HHV-6 in five (18.5\%) and HHV-7 infection in $19(70 \%)$ of donors. Active B-herpesviruses infection occurred in four (15\%) donors and of them two (7.5\%) had active CMV and 2 had active HHV-7 infection.

ß-herpesviruses genomic sequence detection in PBL DNA samples of the 50 recipients before RT identified latent/persistent CMV infection in five (10\%), HHV-6 in ten $(20 \%)$ 
and HHV-7 infection in 39 (78\%). At three months after RT active $B$-herpesviruses infection (plasma viremia) was detected in 27 of $46(58.7 \%)$ recipients, including twelve (26\%) CMV, four (8.6\%) HHV-6, nine (19.5\%) HHV-7 and two $(4.3 \%)$ dual HHV-6 and HHV-7 infection cases. To analyze the different clinical and immunological outcomes in patients with active HHV-6 and HHV-7 infection, the recipients were divided into three groups: Group I, with active HHV-6 infection $(\mathrm{n}=4)$; Group II, with active HHV-7 infection $(\mathrm{n}=9)$ and Group III (control) without active infection $(n=31)$. Two patients with dual active $\beta$-herpesviruses infection were excluded due to small sample size.

Demografic and clinical data on recipients with and without active $\beta$-herpesviruses infection are given in Table 1 . The three patient groups showed no significant differences in demographic parameters. The incidence of acute CMV infection and AR did not significantly differ between the patients who developed active $\beta$-herpesviruses infection and those who did not. Interestingly, patients without active $\beta$-herpesviruses infection showed a higher rate of acute CMV infection (29\%) compared to patients in the group with active HHV-6 (0\%) and HHV-7 (11.1\%), respectively. Compared with the control group (32\%), AR rate was slightly higher in patients with active HHV-6 infection $(50 \%)$, but again, without statistical significance. There was also no significant difference in graft function at 3 and 12 months among the groups. The mean serum creatinine at 12 months was even lower in patients with active HHV-7 than in the control group ( 0.11 vs $0.13, P>0.05)$.

Table 2 gives the numbers of lymphocytes in subsets in the peripheral blood of control group patients with latent/persistent infection compared with the numbers of cells detected in the patients with active HHV-6 and HHV-7 infection at different times after RT.

Counts of CD3+, CD4+ and CD8+ cells were considerably lower before RT, but no significant changes between the three groups were found. Also, there were no significant changes in CD4+/CD8+; CD19+ and CD25+ counts in the study groups. At three months after RT, higher CD3+ and CD4+ cell counts were observed only in the HHV-7 group compared to control group (1.14 vs $0.73, P>0.05$ and 0.59

MAIN DEMOGRAPHIC AND CLINICAL CHARACTERISTICS OF THE PATIENTS INCLUDED IN THE STUDY

\begin{tabular}{|c|c|c|c|c|}
\hline & HHV-6 & HHV-7 & Control & $P$ \\
\hline Patients (n) & 4 & 9 & 31 & \\
\hline Recipient age (years) & $41.7 \pm 8.1$ & $43.8 \pm 13.9$ & $45.7 \pm 14.5$ & 0.927 \\
\hline Number of retransplants & 0 & $1(11.1 \%)$ & $6(19.3 \%)$ & $* 0.281 ; * * 0.437$ \\
\hline Donor age (years) & $46.4 \pm 12.1$ & $47.2 \pm 8.3$ & $46.2 \pm 10.2$ & 0.982 \\
\hline ATG induction therapy & 0 & 0 & $3(9.6 \%)$ & $* 0.378$ \\
\hline Prophylaxis with valganciclovir & $3(75 \%)$ & $6(66.6 \%)$ & $18(58.0 \%)$ & \\
\hline Acute rejection incidence & $2(50 \%)$ & $3(33.3 \%)$ & $10(32.2)$ & $* 0.425 ; * * 0.624$ \\
\hline \multicolumn{5}{|l|}{ Graft function (S-Cr, mmol/L) } \\
\hline at 3 months & $0.137 \pm 0.042$ & $0.118 \pm 0.024$ & $0.125 \pm 0.033$ & $* 0.515 ; * * 0.599$ \\
\hline at 12 months & $0.140 \pm 0.045$ & $0.118 \pm 0.025$ & $0.138 \pm 0.056$ & $* 0.965 ; * * 0.315$ \\
\hline
\end{tabular}

HHV-6 and HHV-7, human herpesviruses; $* P$ controls versus group I; **P controls versus group II

LYMPHOCYTE COUNTS BY SUBSETS IN RECIPIENTS WITH LATENT/PERSISTENT AND ACTIVE ß-HERPESVIRUSES INFECTION

\begin{tabular}{|c|c|c|c|c|c|}
\hline Cell subset & Control & HHV-6 & $P$ controls vs HHV-6 & HHV-7 & $P$ controls vs $\mathrm{H}$ \\
\hline \multicolumn{6}{|l|}{ before RT } \\
\hline \multicolumn{6}{|l|}{ CD3+ } \\
\hline CD4+ & $0.650 \pm 0.749$ & $0.800 \pm 0.589$ & 0.715 & $0.487 \pm 0.372$ & 0.533 \\
\hline CD8+ & $0.37 \pm 0.43$ & $0.45 \pm 0.38$ & 0.723 & $0.27 \pm 0.25$ & 0.520 \\
\hline CD4+/CD8+ & $0.27 \pm 0.32$ & $0.41 \pm 0.36$ & 0.535 & $0.21 \pm 0.17$ & 0.593 \\
\hline CD19+ & $1.468 \pm 0.468$ & $1.167 \pm 0.569$ & 0.678 & $1.443 \pm 0.732$ & 0.917 \\
\hline CD25+ & $0.092 \pm 0.117$ & $0.200 \pm 0.133$ & 0.210 & $0.092 \pm 0.085$ & 0.883 \\
\hline 3 months after RT & $0.044 \pm 0.068$ & $0.048 \pm 0.038$ & 0.366 & $0.013 \pm 0.013$ & 0.182 \\
\hline \multicolumn{6}{|l|}{ CD3+ } \\
\hline \multicolumn{6}{|l|}{ CD4+ } \\
\hline CD8+ & $0.734 \pm 0.685$ & $0.842 \pm 0.506$ & 0.301 & $1.149 \pm 0.735$ & 0.131 \\
\hline CD4+/CD8+ & $0.373 \pm 0.403$ & $0.485 \pm 0.293$ & 0.331 & $0.591 \pm 0.370$ & 0.155 \\
\hline CD19+ & $0.322 \pm 0.325$ & $0.370 \pm 0.228$ & 0.252 & $0.541 \pm 0.431$ & 0.107 \\
\hline \multirow[t]{3}{*}{ CD25+ } & $1.335 \pm 0.818$ & $1.325 \pm 0.419$ & 0.954 & $1.244 \pm 0.665$ & 0.768 \\
\hline & $0.062 \pm 0.059$ & $0.070 \pm 0.063$ & 0.139 & $0.111 \pm 0.071$ & 0.043 \\
\hline & $0.014 \pm 0.016$ & $0.011 \pm 0.010$ & 0.064 & $0.031 \pm 0.034$ & 0.040 \\
\hline
\end{tabular}

RT, renal transplant; HHV-6 and HHV-7, human herpesviruses 
vs $0.37, P>0.05$, respectively). Compared with the control group, the HHV-7 group had significantly increased CD19+ and CD25+ cell counts $(P<0.05$ and $P<0.05$, respectively).

\section{DISCUSSION}

Our study was hindered by the small study groups, which resulted in lack of statistical significance for many parameters. Consistent with our previous studies, we found high incidence of latent/persistent CMV, HHV-6 and HHV-7 infection in renal donors and recipients $(26 \% ; 18.5 \% ; 70 \%$ and $10 \% ; 20 \%$ and $78 \%$, respectively). In contrast to our previous studies, a lower overall rate of active CMV, HHV-6 and HHV-7 infection was found in this study (26\%; $19.5 \%$ and $4.3 \%$, respectively). This may be due to the more intensive prophylaxis with valganciclovir used in recent years. We did not find significant association between active $\beta$-herpesviruses infection and AR and graft function in recipients at different times after RT. The CD3+; CD4+ and CD8+ cell counts were considerably lower before RT, indicating impaired cellular immune function in patients with end-stage renal failure. Secondary immune failure in uremia is multi-faceted and is influenced by uremic intoxication per se, by altered renal metabolism of immunologically active proteins and by specific effects of renal replacement therapy (Girndt et al., 1999). Interestingly, CD19+ and CD25+ cell counts were significantly higher in the HHV-7 group compared with the control group three months after RT $(P<0.05$ and $P>0.05$, respectively). It is possible that increase in expression of CD19+ and CD25+ cells in the HHV-7 group may be caused by down-regulation of cellular and humoral immune response due to viral indirect immunomodulatory effects (Lusso et al., 1994; Lusso, 2006; Mendez et al., 2001). On the other hand, a normal or slightly lower overall lymphocyte subset count and relatively low rate of complications after RT suggests that the maintenance IS regimen with CsA, MMF and $\mathrm{P}$ does not induce over-immunosuppression in patients after RT.

\section{REFERENCES}

Berneman, Z. N., Ablashi, D. V., Li, G., Eger-Fletcher, M., Reitz, M. S., Jr., Hung, C. L., Brus, I., Komaroff, A. L., Gallo, R. C. (1992). Human herpesvirus 7 is a T-lymphotropic virus and is related to, but significantly different from human herpesvirus 6 and human cytomegalovirus. Proc. Natl. Acad. Sci. USA, 89, 10552-10556.

Chapenko, S., Folkmane, I., Ziedina, I., Chistyakovs, M., Rozentals, R., Krumina, A., Murovska, M. (2009). Association of HHV-6 and HHV-7 with the development of chronic allograft nephropathy. J. Clin. Virol., 46 (1), 29-32.

Girndt, M., Sester, U., Sester, M., Kaul, H., Köhler, H. (1999). Impaired cellular immune function in patients with end-stage renal failure. Nephrol. Dial. Transplant., 14, 2807-2810.

Lusso, P. (2006). HHV-6 and the immunosystem: Mechanisms of immunomodulation and viral escape. J. Clin. Virol., 37 ( Suppl 1), 4-10.

Lusso, P., Sechiero, P., Crowley, R. W.,Garzino-Demo, A., Berneman, Z. N. (1994). CD4 is a critical component of the receptor for human herpesvirus 7: Interference with human immunodeficiency virus. Proc. Nat Acad. Sci. USA, 91 (9), 3872-3876.

Mendez, J. C., Dockrell, D. H., Espy, M. J., Smith, T. F., Wilson, J. A., Harmsen, W. S., Ilstrup, D., Paya, C. V. (2001). Human beta-herpesvirus interactions in solid organ transplant recipients. J. Infect. Dis., 183, 179-184.

Osman, H. K. E., Peiris, J. S. M., Taylor, C. E., Warwicker, P., Jarrett, R. F., Madeley, C. R. (1996). Cytomegalovirus disease in renal allograft recipients: Is human herpesvirus-7 a cofactor for disease progression?. J. Med. Virol., 48, 295-301.

Razonable, R. R., Brown, R. A., Humar, A., Covington, E., Alecock, E., Paya, C. V.; PV 16000 study group. (2005). Herpesvirus infections in solid organ transplant patients at high risk of primary cytomegalovirus disease. J. Infect. Dis., 192 (8), 1331-1339.

Santoro, F., Kennedy, P. E., Locatelli, G., Malnati, M. S., Berger, E. A., Lusso, P. (1999). CD46 is a cellular receptor for human herpesvirus 6. Cell, 99, 817-827.

Secchiero, P., Carrigan, D. R., Asano, Y., Benedetti, L., Crowley, R. W., Komaroff, A. L., Gallo, R. C., Lusso, P. (1995). Detection of human herpesvirus 6 in plasma of children with primary infection and immunosuppressed patients by polymerase chain reaction. J. Infect. Dis., 171 (2), 273-280.

Snydman, D. R., Emery, V. C. (2001). Human herpesvirus 6 and 7 in solid organ transplant recipients. Clin. Infect. Dis., 32 (9), 1357-1360.

Studahl, M., Bergstrom, T., Ekeland-Sjoberg, K., Ricksten, A. (1995). Detection of cytomegalovirus DNA in cerebrospinal fluid in immunocompetent patients as a sign of active infection. J. Med. Virol., 46, 274-280.

Tanaka, K., Kondo, T., Torigoe, S., Okada, S., Mukai, T, Yamanishi, K. (1994). Human herpesvirus 7: Another causal agent for roseola (exanthem subitum). J. Pediatr., 125, 1-5.

Yamanishi, K. (2001). Human herpesvirus 6 and human herpesvirus 7. In: Fields Virology (pp. 2785-2801). Knipe, D. M., Howley, P. M., Griffin, B. E., Lamb, R. A., Martin, M. A., Roizman, B., Straus, S. E. (eds.). Philadelphia: Lippincott Williams \& Wilkins.

Yoshikawa, T. (2003). Human herpesvirus-6 and-7 infections in transplantation. Pediatr. Transplant., 7, 11-17.

Received 16 November 2012

\section{HHV-6 UN HHV-7 NOVĒRTĒŠANA PACIENTIEM PĒC NIERES TRANSPLANTĀCIJAS}

Cilvēka herpesvīrusu - 6 (HHV-6) un 7 (HHV-7) reaktivācija pēc transplantācijas visbiežāk ir saistīta ar virkni imūnmodulējošo efektu: citomegalovīrusa (CMV) infekcijas aktivāciju, oportūnistisko infekciju pieaugumu, transplantāta disfunkciju un akūtu transplantāta atgrūšanu. Šajā pētījumā tika analizētas klīniskās un imunoloǵiskās konsekvences nieres transplantāta (NT) pacientiem ar aktīvu HHV-6 un HHV-7 infekciju. Pētījumā iekḷauti 46 NT pacienti, kam laikā no 2007. g. janvāra līdz 2007. g. decembrim tika analizēti klīniskie, virusoloğiskie un imunoloğiskie rādītāji. Pacienti tika sadalīti trīs grupās: pacienti ar aktīvu HHV-6 infekciju (I grupa), pacienti ar aktīvu HHV-7 infekciju (II grupa) un pacienti bez aktīvas infekcijas (kontroles grupa). Vidējais novērošanas laiks bija $14 \pm 2,5$ mēneši. Trīs mēnešus pēc NT aktīva CMV infekcija tika atklāta divpadsmit (26\%) pacientiem, HHV-6 - četriem (8.6\%) pacientiem, bet HHV-7 deviniiem (19.5\%) pacientiem. Netika atklāta aktīvas ß-herpesvīrusu infekcijas asociācija ar akūtu transplantāta atgrūšanu un/vai transplantāta disfunkciju dažādos laika periodos pēc NT. Ievērojami samazinātas CD3+; CD4+ un CD8+ limfocītu subpopulācijas bija tikai pirms NT. Trīs mēnešus pēc NT CD19+ un CD25+ šūnu skaits bija ievērojami augstāks pacientiem ar aktīvu HHV-7 infekciju nekā kontroles grupā $(P<0.05)$. Pêtījumā netika atklātas nozīmīgas atšḳirības klīniskajos un imunoloğiskajos rādītājos pacientiem ar vai bez aktīvas $ß$-herpesvīrusu infekcijas. 